DOI: $10.24850 / \mathrm{j}-$ tyca-2021-05-03

Articles

\title{
Numerical validation of a design methodology for cross- flow turbine type Michell-Banki
}

\section{Validación numérica de una metodología de diseño para turbinas de flujo cruzado tipo Michell-Banki}

Steven Galvis-Holguin ${ }^{1}$, ORCID: https://orcid.org/0000-0003-45119454

Jorge Sierra-Del-Rio², ORCID: https://orcid.org/0000-0002-0057-7454

Diego Hincapié-Zuluaga3, ORCID: https://orcid.org/0000-0003-19936776

Edwin Chica-Arrieta4, ORCID: https://orcid.org/0000-0002-5043-6414

${ }^{1}$ Engineering Faculty, Instituto Tecnológico Metropolitano, Medellín, Colombia, stevengalvis221631@correo.itm.edu.co

2Engineering Faculty, Institucion Universitaria Pascual Bravo-Research Groupe GIIAM, Medellín, Colombia, jsierrad@pascualbravo.edu.co

${ }^{3}$ Engineering Faculty, Instituto Tecnológico Metropolitano, Medellín, Colombia, diegohincapie@itm.edu.co 
4Engineering Faculty, Universidad de Antioquia, Medellín, Colombia, edwin.chica@udea.edu.co

Correspondence author: Jorge Sierra-Del-Rio, jsierrad@pascualbravo.edu.co

\begin{abstract}
The aim of this study is to validate, by means of CFD simulation, the effectiveness of a new design methodology formed of a set of updated equations, which allows the design of each of the MBT components to improve its efficiency. In this study, a rigorous investigation of the MBT literature was carried out, where the most influential design parameters and equations in maximum efficiency were determined. Finally, the design of the MBT is carried out with the most relevant equations found in the literature and the design of the MBT is validated by fluid-dynamic tests. It is concluded that the proposed methodology for the design of the MBT can reach efficiencies up to $83 \%$, which is satisfactory to solve the lack of complete design methods for the sizing of the different components of the MBT (nozzle, runner and housing), according to the flow conditions of the installation site.
\end{abstract}

Keywords: Turbomachines, pico-hydroelectric, efficiency, CFD.

\title{
Resumen
}


El objetivo de este estudio consiste en validar mediante simulación CFD la efectividad de una nueva metodología de diseño conformada por un conjunto de correlaciones actualizadas, que permita el diseño de cada uno de los componentes de la MBT, con el fin de mejorar su eficiencia. En este estudio se realizó una investigación rigurosa de la literatura de la MBT, donde se determinaron los parámetros y las ecuaciones de diseño más influyentes en la eficiencia máxima. Finalmente, el diseño de la MBT se realiza con las correlaciones más relevantes encontradas en la literatura y el diseño de la MBT se valida mediante pruebas fluidodinámicas. Se concluye que la metodología propuesta para el diseño de la MBT puede alcanzar eficiencias hasta del $83 \%$, lo cual es satisfactorio para resolver la falta de métodos de diseño completos para el dimensionamiento de los diferentes componentes de la MBT (inyector, rotor y carcasa) de acuerdo con las condiciones de flujo del lugar de instalación.

Palabras clave: turbomáquinas, pico-hidroeléctricas, eficiencia, CFD.

Received: $26 / 02 / 2020$

Accepted: 15/09/2020

\section{Introduction}




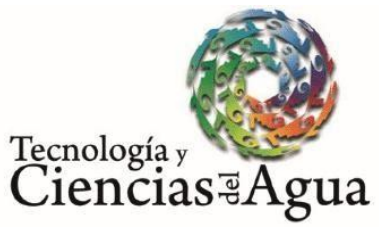

2021, Instituto Mexicano de Tecnología del Agua

Open Access bajo la licencia CC BY-NC-SA 4.0

(https://creativecommons.org/licenses/by-nc-sa/4.0/)

Due to the economy in the competitive market, modernization and constant population growth, several studies predict a huge increase in electric energy consumption for the coming decades, especially in developed countries. Since 2015, hydroelectric energy constitutes about $61 \%$ of total global renewable energy. From this, the small and microhydroelectric power plants contribute around $7 \quad \%$ (TesfayeWoldemariam, Lemu, \& Wang, 2018). This technology offers a great exploitation potential as an energy generation alternative from unconventional sources of renewable energy, particularly in noninterconnected zones -NIZ- of developing countries, with reduced impact in the ecosystem, compared to the big hydroelectric power plants (Paish, 2002). On the other hand, they represent the least expensive technology of electricity generation compared to solar and wind energy (Organization, UNID, 2016).

To take advantage of the available hydroelectric potential implementing small hydro centrals, the use of efficient turbines is required. Traditional technologies of hydroelectric generation systems are integrated by high-efficiency turbines such as Francis, Pelton and Kaplan, and in lesser proportion by MBT (Paredes-Gutiérrez, PalacioHiguita, \& Goméz-Gómez, 2008), despite comparative advantages in its simplicity of design, low fabrication cost and little variation of efficiency with considerable changes in operating conditions (Dragomirescu, 2016). 


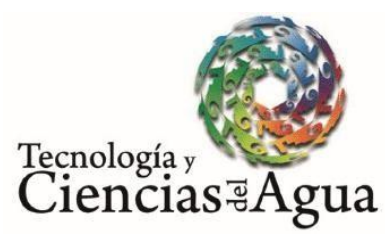

2021, Instituto Mexicano de Tecnología del Agua

Open Access bajo la licencia CC BY-NC-SA 4.0

(https://creativecommons.org/licenses/by-nc-sa/4.0/)

Contrary to the different optimization approaches both numerical and experimental performed in the last decades (Olade, 1987), the design methodologies of the MBT must be updated (TesfayeWoldemariam et al., 2018) since there are currently new materials with better physical properties, equipment and manufacturing techniques that allow obtaining improved components. Thus, a good methodology design for sizing the MBT components will have a significant impact on the performance, which will increase its implementation feasibility as a generation technology for appropriate site conditions ( $Q$ and $H$ ).

The MBT is a turbomachine that takes advantage of the fluid kinetic energy and transforms it into an angular momentum, which is converted into electrical energy through a generator (Ceballos, Valencia, Zuluaga, Del-Rio, \& García, 2017). Based on the reported research in the state of the art, a similar turbine design composed of three bodies is implemented: nozzle, runner and housing, as shown in Figure 1(A). In the MBT, the fluid enters by the nozzle, increasing the velocity of the fluid and directing it into the runner inlet, while maintaining the attack angle and constant speed along the azimuth position corresponding to the interface between the nozzle outlet and the inlet of the runner. The cross-flow transfers the energy in two stages of the runner as detailed in Figure $1(B)$. In the first and second stages, the fluid energy is delivered at 70 and $30 \%$, respectively (Chiyembekezo, Cuthbert, \& Torbjorn, 2014; Ceballos et al., 2017). 

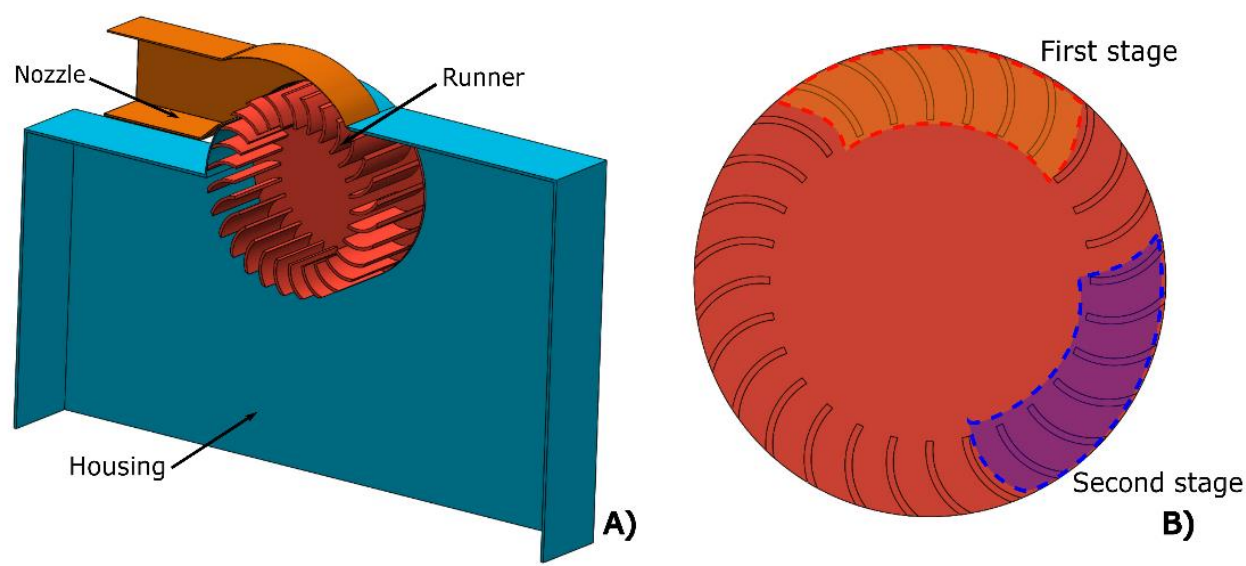

Figure 1. MBT: A) Isometric view; B) runner side view.

Different design methodologies of each one of the components from the MBT, especially for the nozzle and the runner based on studies both numerical and experimental, are found in the literature. As for modifications in the nozzle, Adhikari and Wood (2017) conducted a study of the geometry's effect of the nozzle rear-wall in the efficiency of the MBT using computational simulations, showing an increase of $18 \%$ in the turbine hydraulic performance over the model without the modification. Then, in a later study, Adhikari and Wood (2018) carried out a CFD research in which he proposes an electronic device that regulates the nozzle's inlet in front of flow changes, to keep the velocity and fluid's attack angle constant while entering the runner, achieving efficiencies up to $88 \%$. Finally, regarding the nozzle, Rantererung, Tandiseno and Malissa (2019) conducted the design of a 5 kW MBT for a NIZ. This design consists of the use of multi-nozzles, looking to determine the number of nozzles needed for the best turbine 


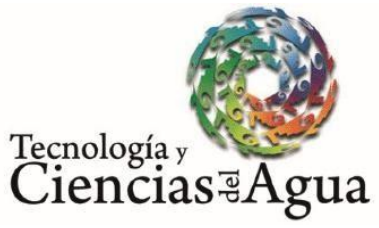

2021, Instituto Mexicano de Tecnología del Agua

Open Access bajo la licencia CC BY-NC-SA 4.0

(https://creativecommons.org/licenses/by-nc-sa/4.0/)

performance. The model was tested with 1,2 and 3 nozzles, concluding that the best behaviour of the MBT occurs when there are three nozzles generating $4.259 \mathrm{~kW}$.

Regarding the modification in the runner, Sammartano, Aricò, Carravetta, Fecarotta and Tucciarelli (2013), and Chichkhede, Verma, Gaba and Bhowmick (2016) carried out a 2D and 3D CFD analysis on the optimal design for the MBT, based on improvement criteria founded on geometric parameters that significantly affect the turbine efficiency such as the position, number, shape of the blades and the fluid attack angle, obtaining an efficiency of $86 \%$ using 35 blades and an attack angle of 22. On the other hand, modifications in the blades of the runner were found in the literature. Arellano-Vilchez (2015) conducted a study using CFD techniques, examining the runner's blades behaviour with and without sharp edges, considering also the thickness of the blades, concluding that using sharp blades improves the hydraulic performance of the MBT. Finally, regarding the runner's geometric modifications, the research carried out by Popescu (2017) analyses the low efficiencies of the MBT through CFD caused by the fluid interaction with the runner's shaft and flow recirculation at low rotational regime, determining that, when the runner works without shaft, the efficiency increases $5 \%$.

According to the review of the state of art, there are different equations to design the nozzle and runner of the MBT. However, each of these equations was performed separately, therefore, it is not possible to show whether, at the time of concatenating these equations for the design of an MBT, the same results that are presented separately will be 
Tecnología y

Ciencias ฐAgua
2021, Instituto Mexicano de Tecnología del Agua

Open Access bajo la licencia CC BY-NC-SA 4.0

(https://creativecommons.org/licenses/by-nc-sa/4.0/)

guaranteed. Hence, the importance of having an updated design methodology for the dimensioning of each of the elements of the MBT is evident, using equations developed through experimental and/or numerical methodologies. The objective of this study is to validate, through CFD simulation, the effectiveness of a new design methodology formed of a set of updated equations, which allows the design of each of the MBT components to improve their efficiency.

\section{Methodology}

\section{Govern equations}

Figure 2 shows a schematic illustration of the MBT, to show all the geometric parameters that were considered in this study. 


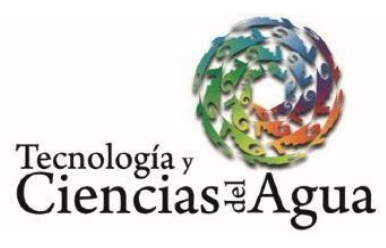

2021, Instituto Mexicano de Tecnología del Agua

Open Access bajola licencia CC BY-NC-SA 4.0

(https://creativecommons.org/licenses/by-nc-sa/4.0/)

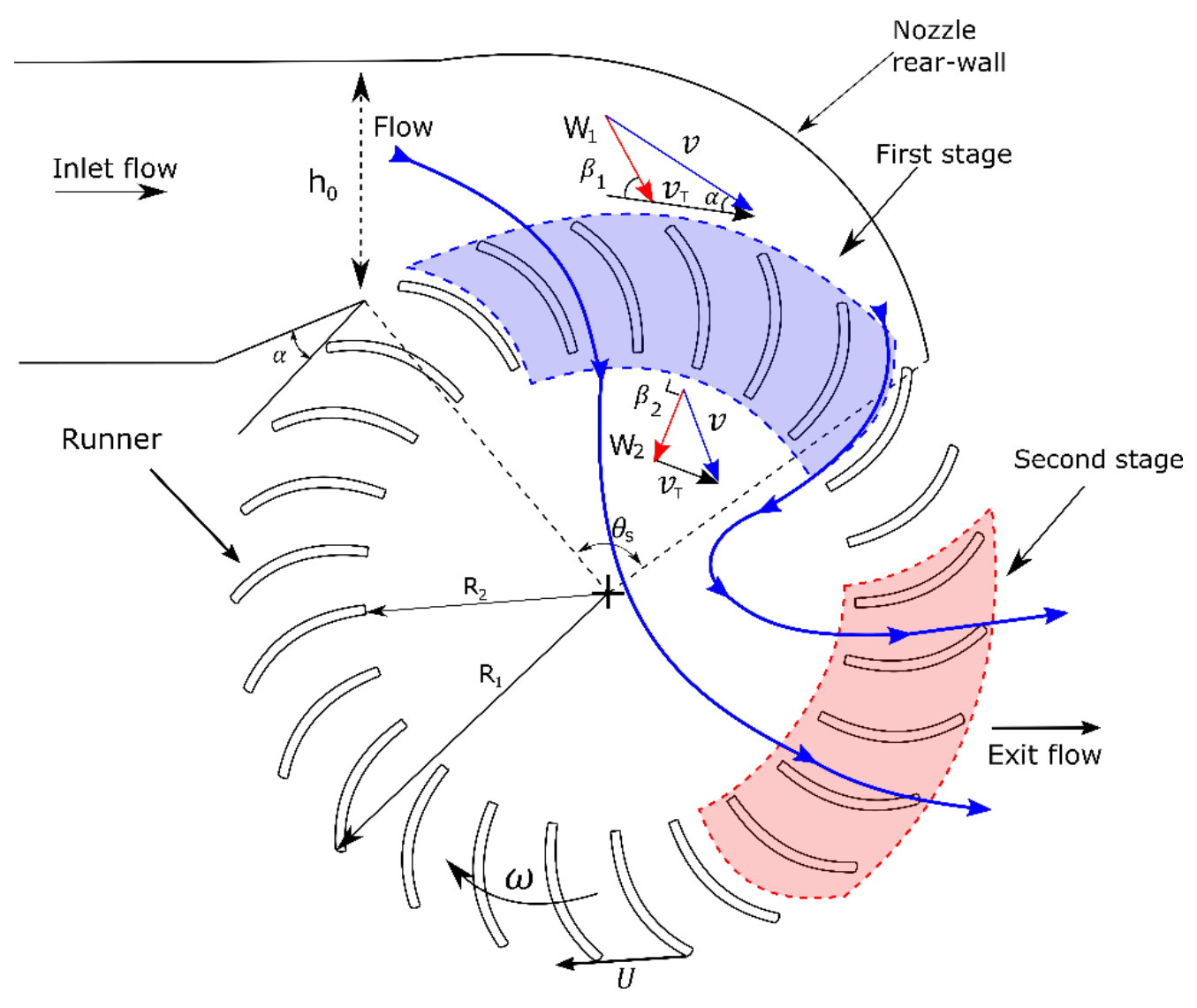

Figure 2. Schematic illustration of the basic design of an MBT. Source: Adapted from Adhikari and Wood (2017).

To start with the design of the MBT, the operating conditions must be taken as the input parameters according to the site conditions, $Q$ and $\mathrm{H} ; 20 \mathrm{l} / \mathrm{s}$ and $0.5 \mathrm{~m}$, respectively. Afterwards, the runner design starts, using the external diameters $\left(D_{\text {ext }}\right.$ ) of the runner according to the flow/head ratio of Table 1 (Paz, Carrocci, Filho, \& Luna, 2007). Then, the internal diameter $\left(D_{\text {int }}\right)$ is calculated by Equation (1); the flow 
velocity $(v)$ at the runner inlet is determined by Equation (2) (Adanta, Siswantara, \& Prakoso, 2018).

Table 1. Selection of the rotor diameter. Source: Paz et al. (2007).

\begin{tabular}{|c|c|}
\hline $\boldsymbol{Q}\left(\boldsymbol{m}^{3} / \boldsymbol{s}\right) / \sqrt{\boldsymbol{H}(\boldsymbol{m})}$ & External rotor diameter (mm) \\
\hline $0.02236-0.04743$ & 200 \\
\hline $0.04743-0.07906$ & 300 \\
\hline $0.07906-0.11068$ & 400 \\
\hline $0.11068-0.15812$ & 500 \\
\hline
\end{tabular}

$0.68=\frac{D_{\text {int }}}{D_{\text {ext }}}$

$v=C_{v} \sqrt{2 \cdot g \cdot H}$

Where $C_{v}$ corresponds to the loss factor inside the nozzle, ideally, $C_{v}$ is considered 1 ; while experimentally, Sammartano, Morreale, Sinagra and Tucciarelli (2016) report values equal to 0.95. After, for the selection of the fluid attack angle $(\alpha)$, different numerical and experimental studies propose values between 12 and $22^{\circ}$ (Chichkhede et al., 2016; Warjito, Siswantara, Adanta, \& Prakoso, 2017). This 
Tecnología y

Ciencias $\stackrel{\Xi}{\varpi}$ Aua
2021, Instituto Mexicano de Tecnología del Agua

Open Access bajo la licencia CC BY-NC-SA 4.0

(https://creativecommons.org/licenses/by-nc-sa/4.0/)

determines the relative velocity angle $\left(\beta_{1}\right)$ concerning the runner using Equation (3) given by Sammartano et al. (2013):

$2 \tan (\alpha)=\tan (\alpha)$

Based on studies conducted by Warjito et al. (2017) and Sammartano et al. (2013), $\beta_{2}$ is selected. Where the angles of the blades with respect to the tangent of the inner and outer diameters should be $\beta_{1 b}$ and $\beta_{2 b}$, respectively (Figure 3).

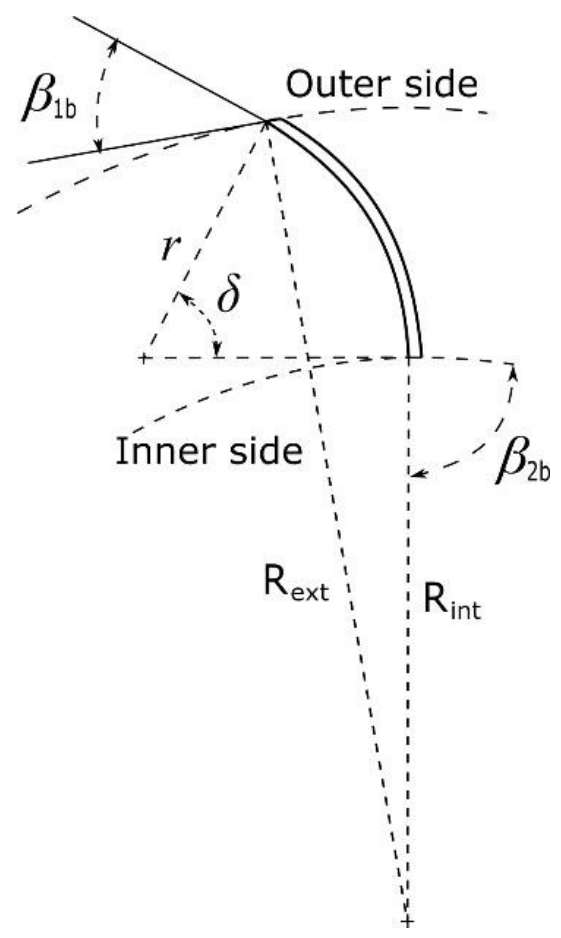

Figure 3. Blade geometry of an MBT. Source: Adapted from Sammartano et al. (2013). 
2021, Instituto Mexicano de Tecnología del Agua

Open Access bajo la licencia CC BY-NC-SA 4.0

(https://creativecommons.org/licenses/by-nc-sa/4.0/)

Then, the blade radius $(r)$ and blade curvature angle $(\delta)$ were calculated using Equations (4) and Equation (5), respectively (Olade, 1987):

$r=\frac{D_{\text {ext }}}{4 \cos \beta_{1}} \cdot\left(1-\left(\frac{D_{\text {int }}}{D_{\text {ext }}}\right)^{2}\right)$

$\delta=2 \tan ^{-1}\left(\frac{\cos \left(\beta_{1}\right)}{\left(\frac{D_{\text {int }}}{D_{\text {ext }}}\right)+\sin \left(\beta_{1}\right)}\right)$

To calculate the width of the runner, the optimum number of blades $\left(N_{b}\right)$ must be obtained using Table 2 .

Table 2. Selection of the number of runner blades. Source: Paz et al. (2007).

\begin{tabular}{|c|c|}
\hline External rotor diameter ( $m$ m) & Number of blades \\
\hline 200 & 22 \\
\hline 300 & 24 \\
\hline 400 & 26 \\
\hline 500 & 28 \\
\hline
\end{tabular}


2021, Instituto Mexicano de Tecnología del Agua

Open Access bajola licencia CC BY-NC-SA 4.0

(https://creativecommons.org/licenses/by-nc-sa/4.0/)

Then, $h_{0}$ is calculated by Equation (6), which corresponds to the nozzle throat; where $\theta_{s}$ is the opening of the nozzle at the entrance of the runner given by Adhikari and Wood (2017), as shown in Figure 4. Having this data, it is possible to calculate the width of the runner by Equation (7) (Olade, 1987):

$\frac{h_{0}}{R_{\text {ext }} \cdot \theta_{s}}=0.37$

$W=\frac{Q \cdot N_{b}}{\pi \cdot D_{\text {ext }} \cdot \cdot \cdot \sin (\alpha) \cdot Z_{a}}$

Where $Z_{a}$ is the number of wet blades in the first stage of the turbine, as shown in Figure 2. Afterwards, the width of the nozzle is calculated by Equation ( 8$)$. Then, the turbine rotation regime $\left(\omega_{\max }\right)$ is determined by Equation (9) (Adhikari \& Wood, 2017):

$B=\frac{W}{1.5}$

$\frac{\omega_{\max } \cdot R_{\text {ext }}}{v}=\frac{1}{2}\left(1+\frac{h_{0}^{2}}{R_{\text {ext }}^{2} \cdot \theta_{s}^{2}}\right)$

The geometric shape of the nozzle rear-wall can be obtained by Equation (10) (Adhikari \& Wood, 2017), where $\theta$ will take values from 0 to $\theta_{s}$ (Figure 4): 
Tecnología y

Ciencias $₫$ Agua
2021, Instituto Mexicano de Tecnología del Agua

Open Access bajola licencia CC BY-NC-SA 4.0

(https://creativecommons.org/licenses/by-nc-sa/4.0/)

$R_{(\theta)}=R_{1}+h_{0}\left(1-\frac{\theta}{\theta_{s}}\right)$

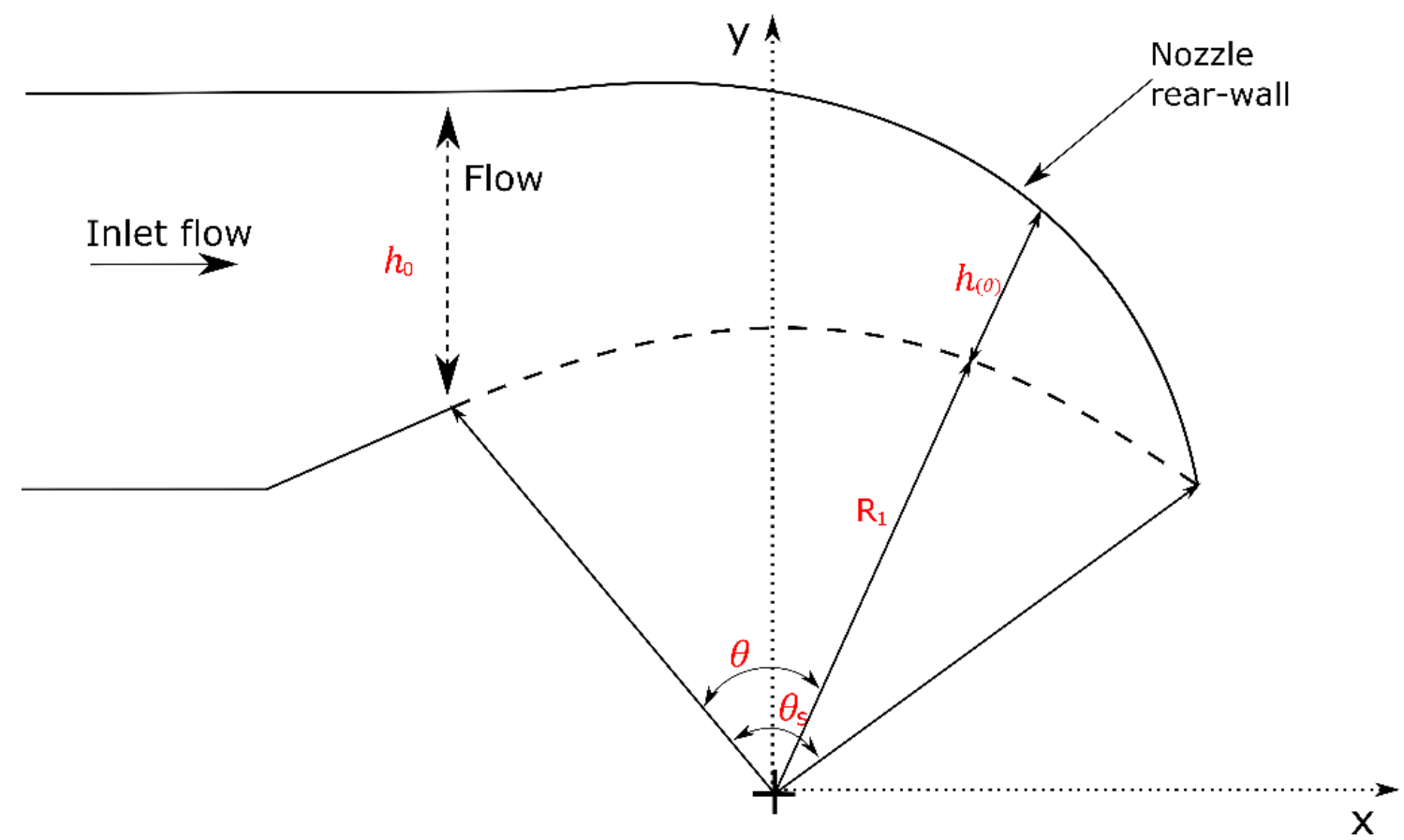

Figure 4. Schematic illustration nozzle rear-wall of an MBT. Source:

Adapted from Adhikari and Wood (2017).

Finally, the efficiency $(\eta)$ of the MBT is determined by Equation (11) (Ceballos et al., 2017) which corresponds to the ratio between the outlet power shaft $\left(P_{\text {out }}=T \cdot \omega\right)$ and the total energy water flow $\left(P_{\text {in }}=\gamma\right.$. $Q \cdot H \cdot \eta)$ 


\section{Computational model}

After performing the design methodology of the MBT based on the govern equations found in the state of art, a simplified design of the elements (runner, nozzle and housing) that constitute the turbine is proposed based on equations (1) to (12); then a Boolean operation is conducted to obtain the internal control volume of the hydraulic machine, which is meshed or discretized in the mesh module in the software Ansys 2019R3 8 ; using tetrahedral elements with advanced curvature and proximity functions, using a minimum element size of 2 $\mathrm{mm}$, which was enough to determine mesh independence (Figure 5) with eight million items with a relative error of less than $1 \%$. 


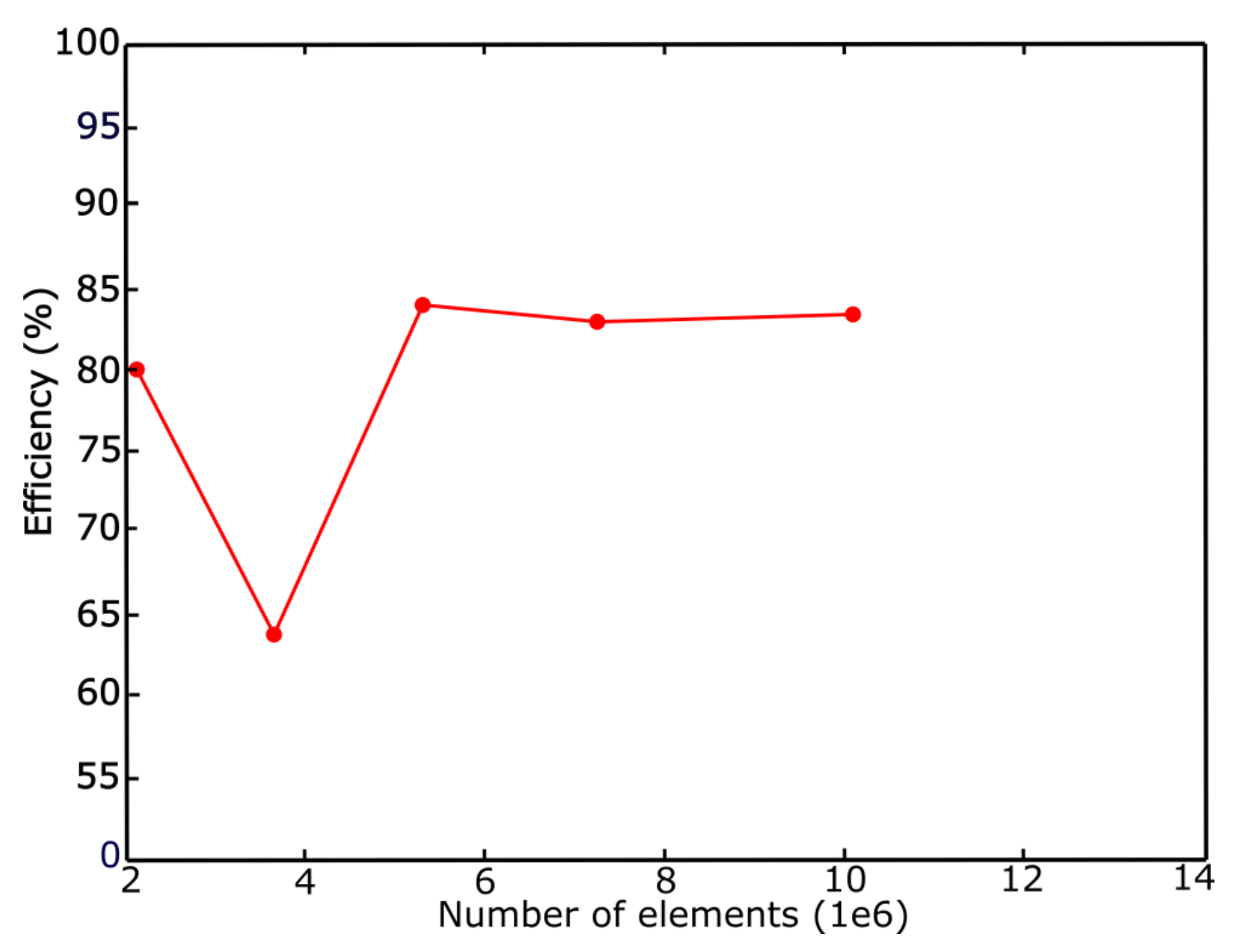

Figure 5. Mesh independence.

Based on different research where the various models of turbulence in similar problems are compared, and on some different computational models, it is found that the standard numeric model $k-\varepsilon$, correctly represents the flow within the MBT. According to different studies and user guides of simulation tools, this model is robust, economical and provides a reasonable accuracy not only for the current problem but also for a wide range of problems. Therefore, the standard model was used in this work for time-dependent analysis, fleeting simulations with a simulation time of 1 second and with a time step of 


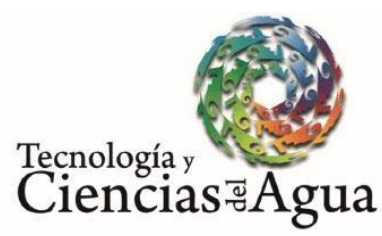

2021, Instituto Mexicano de Tecnología del Agua

Open Access bajo la licencia CC BY-NC-SA 4.0

(https://creativecommons.org/licenses/by-nc-sa/4.0/)

0.001 seconds, considering the homogeneous biphasic model composed of water and air at $25^{\circ} \mathrm{C}$ since this has a lower computational cost than the non-homogeneous. Figure $6(A)$ presents the CFX Ansys $\AA$ configuration; the fluid enters the system by the nozzle (inlet) with a velocity of $2.3 \mathrm{~m} / \mathrm{s}$, then it goes through the ring domain, where it can be possible to configure both of the interfaces so that there can be a data transfer between the rotating (runner) and the stationary domains (housing and nozzle). The first interface is configured between the nozzle, the external ring surface and the housing turbine, as shown in Figure 6(B). For this, a "fluid-fluid" type interface is implemented, with a mesh connection method defined by a "general connection" interface model and no change/mixing model framework for statical domains. The second interface is configured between the internal ring surface and the external runner surface, as shown in Figure 6(C). Similarly, the same as for the first interface, a "fluid-fluid" interface with a "Transient Rotor Stator" configuration for the change/mixing model frame due to the transient fluid conditions between the nozzle and the runner. 
Teçnología y

Ciencias $\approx$ Agua
2021, Instituto Mexicano de Tecnología del Agua

Open Access bajola licencia CC BY-NC-SA 4.0

(https://creativecommons.org/licenses/by-nc-sa/4.0/)

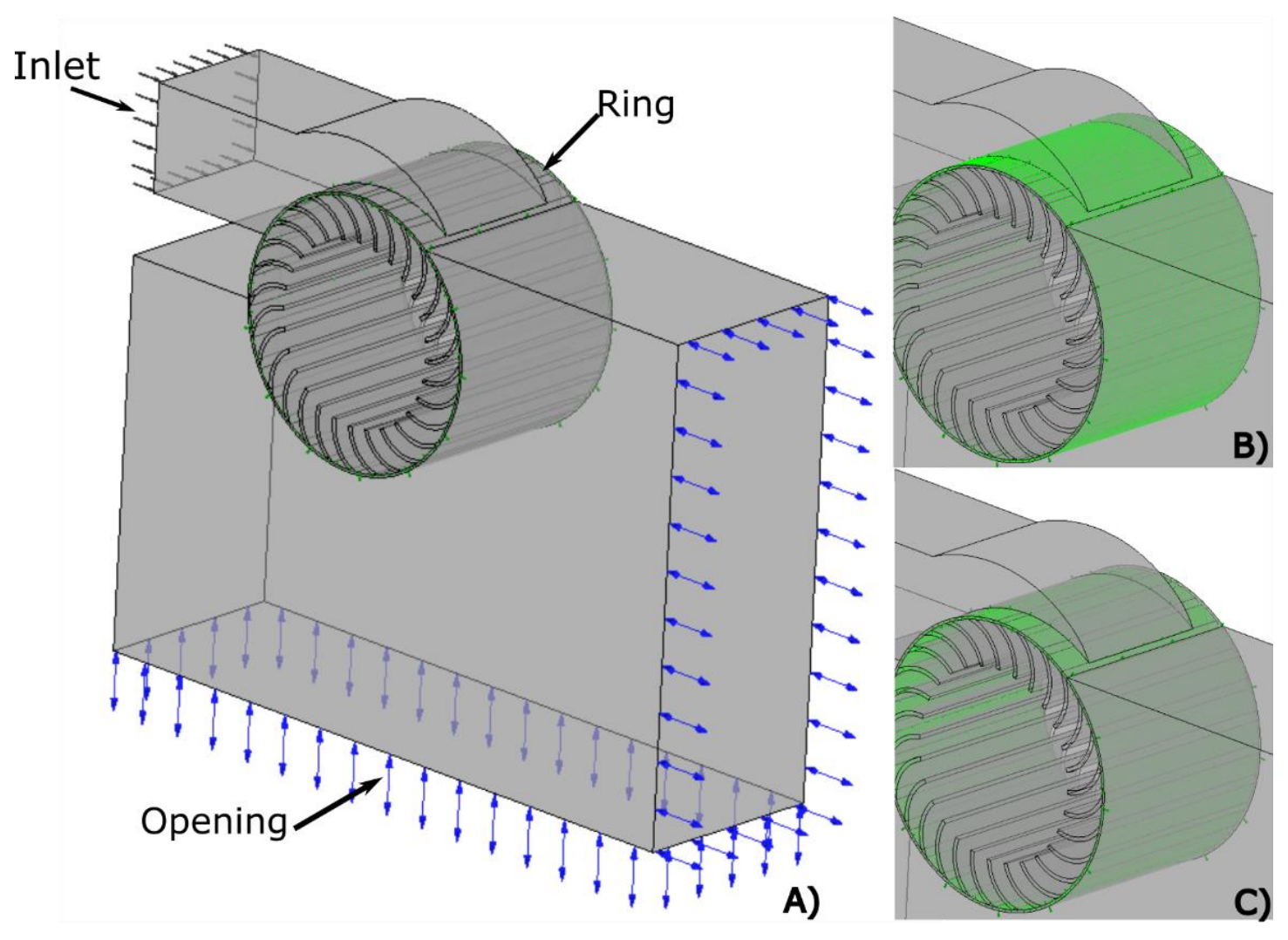

Figure 6. CFX configuration: A) Boundary condition; B) interface housing-nozzle-ring; $C$ ) interface runner-ring.

\section{Results}




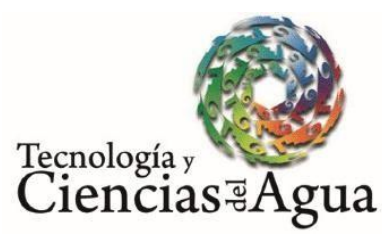

2021, Instituto Mexicano de Tecnología del Agua

Open Access bajo la licencia CC BY-NC-SA 4.0

(https://creativecommons.org/licenses/by-nc-sa/4.0/)

This section presents the results obtained through CFD, after implementing the model configuration studied in CFX Ansys ${ }^{\circ}$ for a net height of $0.5 \mathrm{~m}$ and a real flow simulation of $16.2 \mathrm{l} / \mathrm{s}$ since the pressure was configured for the inlet boundary conditions. Water volumetric fraction, speed and pressure contours obtained by the CFD, which are processed and examined to characterize the influence of the methodology proposed on the turbine performance.

Figure 7 presents efficiency following the speed ratios of the MBT, for the experimental results obtained by Sammartano, Morreale, Sinagra, Collura and Tucciarelli (2014) and the numerical results obtained in this study, conducting six simulations varying the rotational regime of the rotor from 100 to 200 RPM, obtaining a maximum efficiency of $83 \%$ with a rotational regime equal to 160 RPM, similar to the one obtained using the Equation (9) proposed by Adhikari and Wood (2017), with a speed ratio of $\left(\frac{v_{t}}{U}\right)=1.7$. Based on these results, this study shows similarities to the experimental results obtained by Sammartano et al. (2014), who obtained efficiencies of $82.1 \%$ at speed ratios $\left(\frac{v_{t}}{U}\right)$ close to 1.7 , as shown in Figure 7 . 


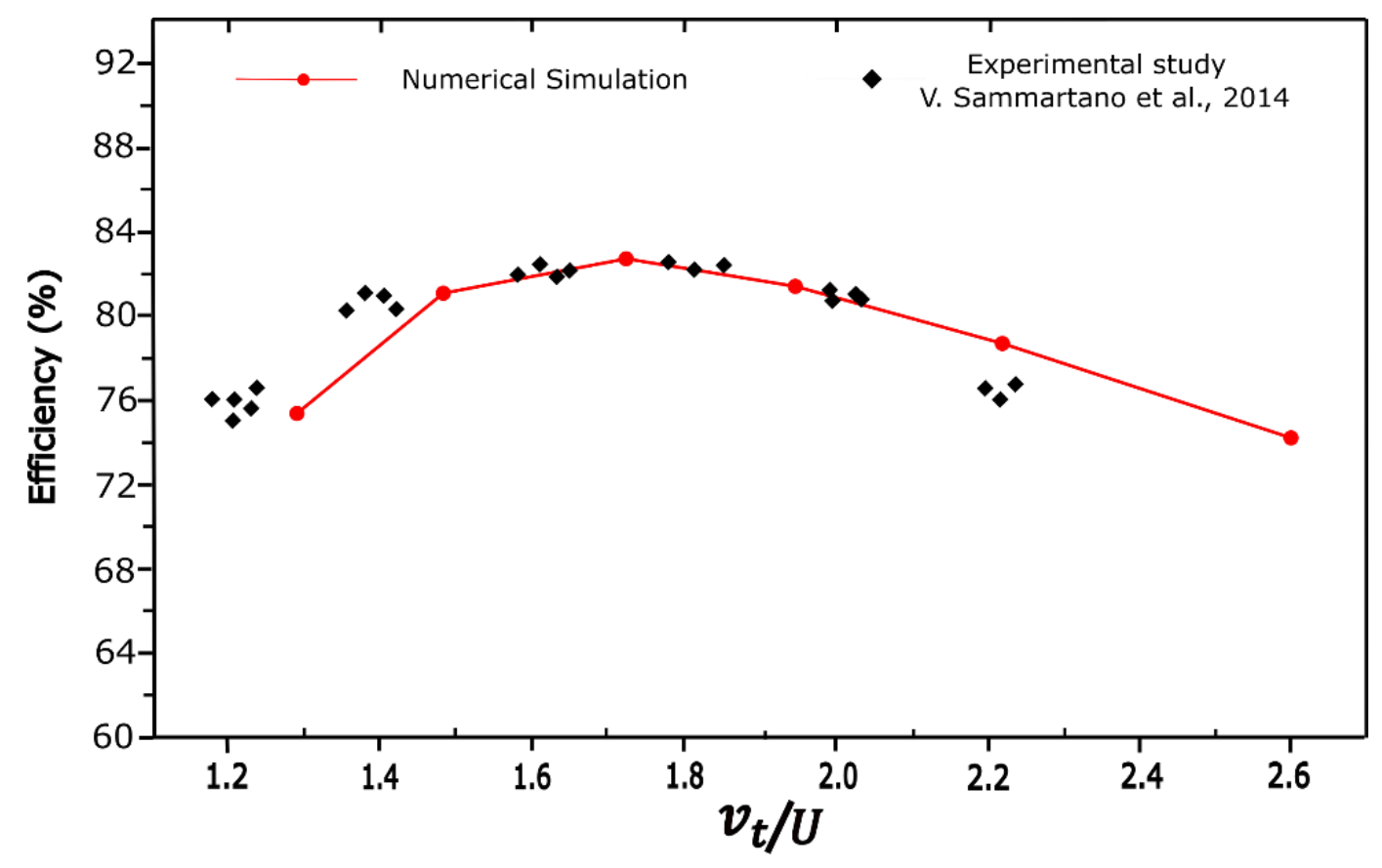

Figure 7. Speed ratio of the MBT.

Figure 8 shows the water volumetric fraction in the (XY) symmetry plane of the MBT, where it can be observed that there is an insignificant flow separation in the first and second stage since the design implemented in the nozzle allows a greater similarity between the angles of the relative fluid speed and the position of the blades ( $\beta_{1}=$ $\left.\beta_{1 b}\right)$, along with the azimuth position at the runner inlet; improving the flow conditions in the inlet and through the rotor, which results in an improvement in the hydraulic performance, agreeing with the results obtained by Adhikari and Wood (2017). Furthermore, it is possible to observe that the flow does not present alterations within the rotor since there is no shaft passing through it. Consequently, the hydraulic 


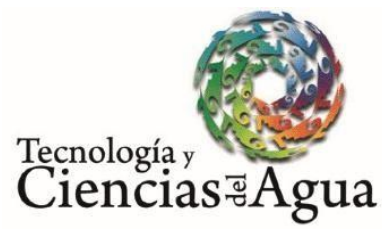

2021, Instituto Mexicano de Tecnología del Agua

Open Access bajo la licencia CC BY-NC-SA 4.0

(https://creativecommons.org/licenses/by-nc-sa/4.0/)

performance improves when compared to a rotor with the shaft, as concluded in the study conducted by Sammartano et al. (2013).

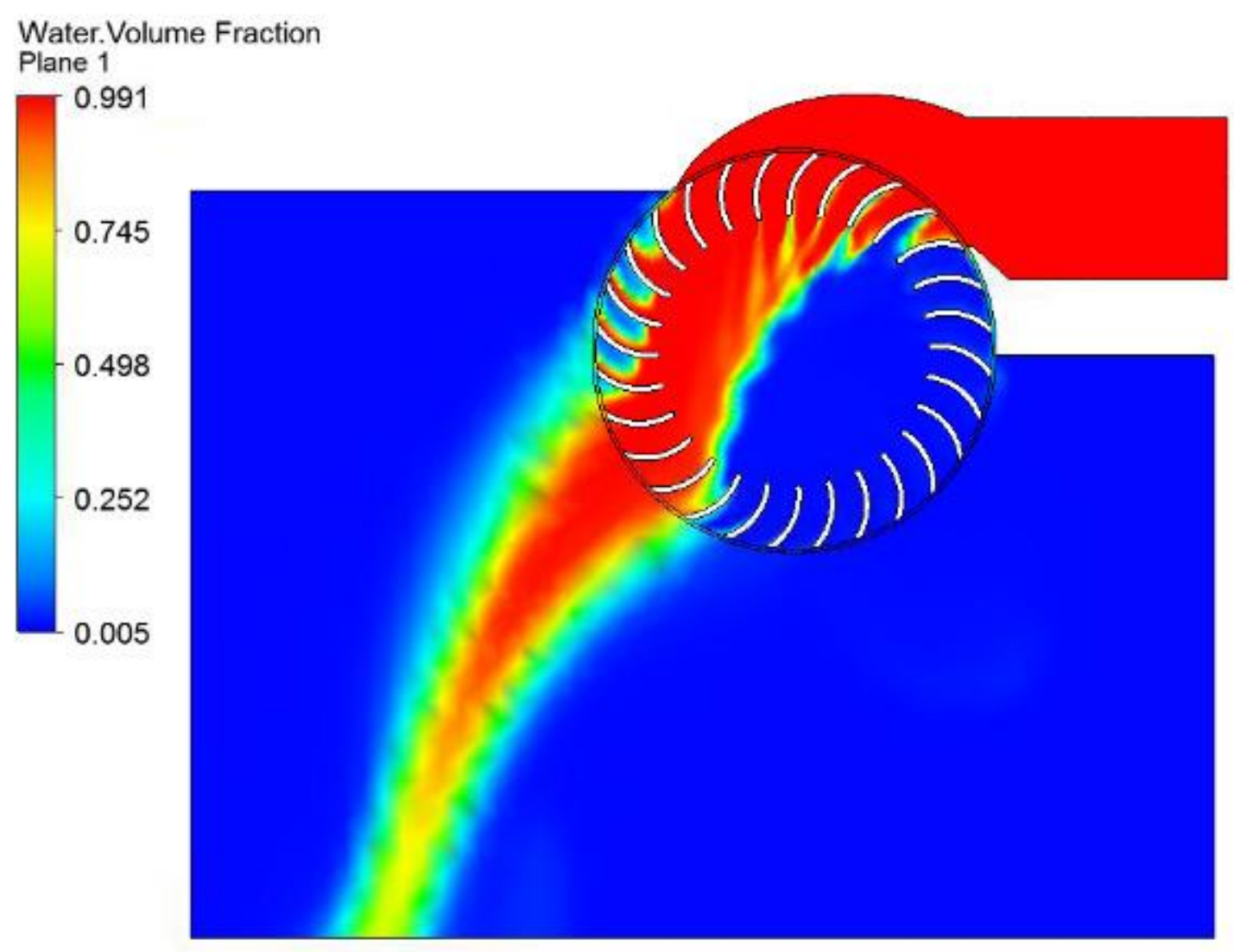

Figure 8. Water's volumetric fraction in the MBT.

Figure 9 presents the velocity vector plotted by velocity magnitude in the $(X Y)$ symmetry plane. In this case, there is an increase of the speed in the reduction of the cross-section of the nozzle, obtaining a nozzle efficiency determined by Equation (2) of around $97 \%$. Then, there is a reduction of the speed at the exit of the first stage, since the fluid 


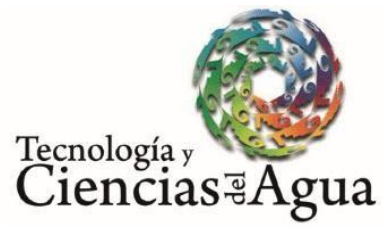

2021, Instituto Mexicano de Tecnología del Agua

Open Access bajo la licencia CC BY-NC-SA 4.0

(https://creativecommons.org/licenses/by-nc-sa/4.0/)

delivers most of its kinetic energy in the first stage (Shepherd, 1956). Immediately afterwards, the cross-flow is generated and the flow transfers back some kinetic energy to the rotor blades during the second stage.

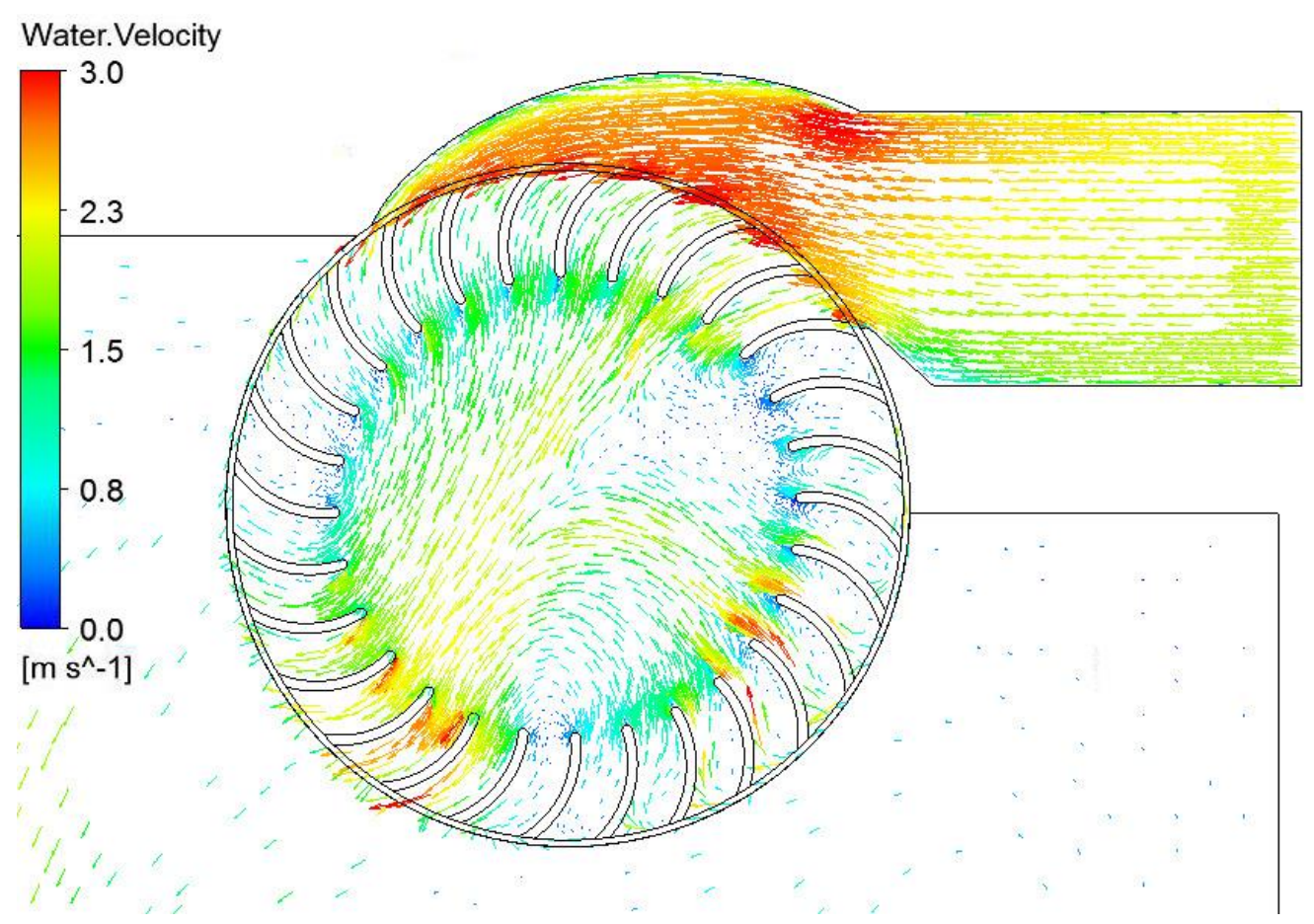

Figure 9. Water velocity in the MBT.

Figure 10 presents the pressure contours of the fluid in the same symmetry plane $X Y$, where the circuit of the fluid through the MBT from the inlet to the outlet can be seen, the assigned values to the green and blue colours indicate the maximum and minimum pressures generated, respectively, by the water jet. It is possible to observe a fluid pressure 
Tecnología y

Ciencias Agua
2021, Instituto Mexicano de Tecnología del Agua

Open Access bajo la licencia CC BY-NC-SA 4.0

(https://creativecommons.org/licenses/by-nc-sa/4.0/)

loss while passing through the turbine, which is due to two factors: the conversion of $\mathrm{H}$ into kinetic energy, and the nozzle leaks. Furthermore, there is also evidence of void pressures happening on the convex sides of the blades during the first and second stages, being more evident in the first stage, as all the blades are submerged. In agreement with the velocity contours presented in Figure 9, where the highest speed deltas are obtained in the blades placed in the first stage. This is advisable since the MBT will work as a reaction turbine; using the pressure difference on the blades to increase the runner's angular momentum (Ceballos et al., 2017).

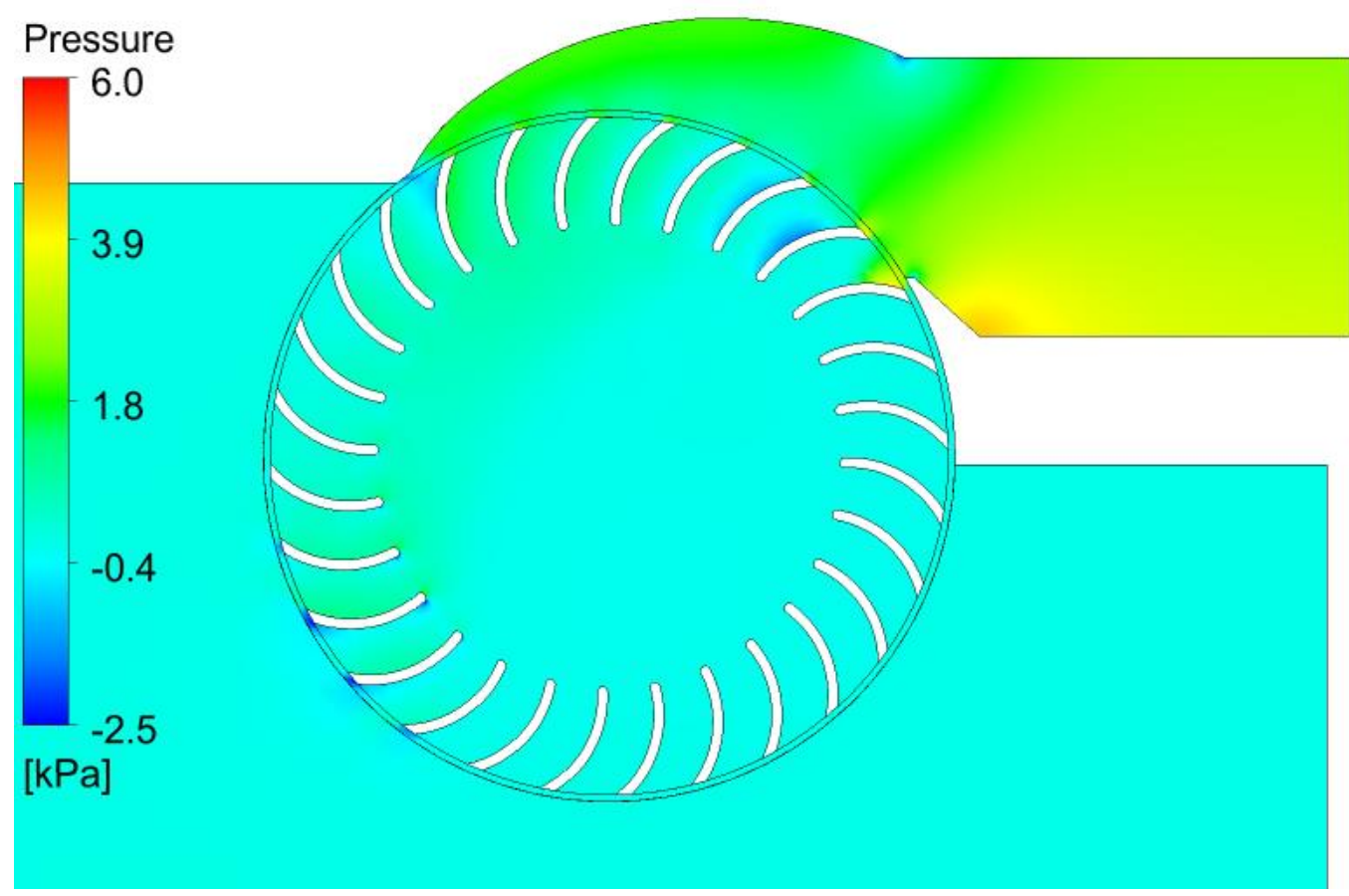

Figure 10. Manometric pressure contour in the MBT. 


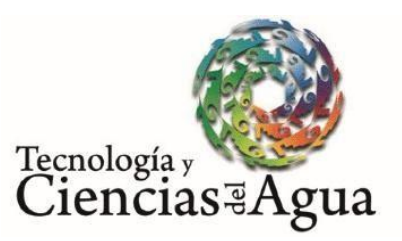

2021, Instituto Mexicano de Tecnología del Agua

Open Access bajo la licencia CC BY-NC-SA 4.0

(https://creativecommons.org/licenses/by-nc-sa/4.0/)

\section{Conclusions}

This paper presents the numerical validation of a new and simple design methodology for the sizing of the MBT, which is commonly used worldwide in small-scale hydroelectric systems. To this effect, an analytic study has been conducted, using different equations for the geometric design of each element of the MBT, especially for the runner and nozzle components, based on numerical and experimental investigations that were used to establish the presented methodology, which was validated using three-dimensional Reynolds-Averaged Navier Stokes (RANS) simulations with the $k-\varepsilon$ turbulence model, a two-phase homogeneous free-surface flow model, and the commercial software ANSYS CFX.

The methodology established in this work agrees to design each of the elements of MBT based on the operating conditions of the installation place ( $\mathrm{Q}$ and $\mathrm{H}$ ); achieving $83 \%$ of hydraulic efficiencies and significantly shortening the time required at the design stage. It is verified that the proposed design methodology for the rotor and the nozzle allows the designer to obtain a high-performance MBT, following the site conditions ( $Q$ and $H$ ). Furthermore, it offers an updated 
alternative to the methodology proposed by Olade (1987), for the design of this kind of turbine.

\section{Further works}

As for future works, it should be important to establish different equations for the new blade rotor design in terms of the site conditions such as $\mathrm{H}$ and $\mathrm{Q}$, integrating new materials and manufacturing techniques that allow fabricating improved geometry blades that can increase the energy transfer at the first and second stage of the rotor. Additionally, modifications at the nozzle rear-wall could improve the velocity profile at the inlet of the runner and the turbine efficiency.

\section{Acknowledgements}

The authors would like to thank the Metropolitan Institute of Technology and its research group on Advanced Materials and Energy MATyER, in the field of Advanced Computing and Digital Design, and the AEG Alternative Energy Group of the University of Antioquia for making its resources available to carry out this project. 
Tecnología y

Ciencias Agua
2021, Instituto Mexicano de Tecnología del Agua

Open Access bajo la licencia CC BY-NC-SA 4.0

(https://creativecommons.org/licenses/by-nc-sa/4.0/)

\section{Nomenclature}

$D_{\text {ext }}=$ Runner external diameter ( $\left.\mathrm{mm}\right)$

$D_{\text {int }}=$ Runner internal diameter $(\mathrm{mm})$

$N_{b}=$ Number of blades

$W=$ Runner width $(\mathrm{mm})$

$B=$ Nozzle width $(\mathrm{mm})$

$h_{0}=$ Nozzle height at runner inlet $(\mathrm{mm})$

$\theta_{s}=$ Nozzle output $\operatorname{arc}\left({ }^{\circ}\right)$

$C_{v}=$ Nozzle loss coefficient

$Z_{a}=$ Number of wet blades

$P=$ Brake power $(\mathrm{CV})$

$U=$ Runner tangential speed $(\mathrm{m} / \mathrm{s})$

$v_{t}=$ Fluid tangential velocity $(\mathrm{m} / \mathrm{s})$

$g=$ Gravity $\left(m / s^{2}\right)$

$R_{B}=$ Blade radius of curvature $(\mathrm{mm})$

$H=\operatorname{Head}(m)$

$Q=$ Flow rate $\left(\mathrm{m}^{3} / \mathrm{s}\right)$ 
$N_{S}=$ Specific number of revolutions

$N_{q}=$ Specific number of revolutions

$v=$ Fluid velocity $(\mathrm{m} / \mathrm{s})$

$T=$ Torque $(N \cdot m)$

\section{Greek symbols}

$\gamma=$ Specific weight $\left(N / \mathrm{m}^{3}\right)$

$\omega=$ Runner speed $(R P M)$

$\delta=$ Blade curvature angle $\left({ }^{\circ}\right)$

$\alpha=$ Angle of attack $\left(^{\circ}\right)$

$\beta_{1}=$ Input angle of relative velocity $\left(^{\circ}\right)$

$\beta_{2}=$ Output angle of relative velocity $\left(^{\circ}\right)$

$\beta_{1 b}=$ Angle of attack of the blade $\left(^{\circ}\right)$

$\beta_{2 b}=$ Blade output angle $\left(^{\circ}\right)$

\section{References}

Adanta, D., Siswantara, A. I., \& Prakoso, A. P. (2018). Performance 


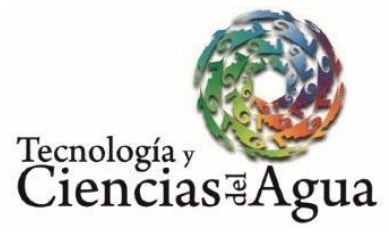

2021, Instituto Mexicano de Tecnología del Agua

Open Access bajo la licencia CC BY-NC-SA 4.0

(https://creativecommons.org/licenses/by-nc-sa/4.0/)

Comparison of NACA 6509 and 6712 on pico hydro type cross-flow turbine by numerical method. Journal of Advanced Research in Fluid Mechanics and Thermal Sciences, 45, 116-127.

Adhikari, R.C., \& Wood, D. H. (2018). Computational analysis of partload flow control for crossflow hydro-turbines. In: Energy for sustainable development, vol. 45 ( $\mathrm{pp}$. 38-45). Recovered from https://doi.org/10.1016/j.esd.2018.04.003

Adhikari, R. C., \& Wood, D. H. (2017). A new nozzle design methodology for high efficiency crossflow hydro turbines. Energy for Sustainable Development, vol. 41 (pp. 139-148). Recovered from https://doi.org/10.1016/j.esd.2017.09.004

Arellano-Vilchez, M. A. (2015). Geometría del álabe del rotor para mejorar el torque en una turbina Michell-Banki (tesis de maestría no publicada). Universidad Nacional del Centro del Perú.

Ceballos, Y. C., Valencia, M. C., Zuluaga, D. H., Del-Rio, J. S., \& García, S. V. (2017). Influence of the number of blades in the power generated by a Michell Banki Turbine. International Journal of Renewable Energy Research, 7(4), 1989-1997.

Chichkhede, S., Verma, V., Gaba, V. K., \& Bhowmick, S. (2016). A simulation based study of flow velocities across cross flow turbine at different nozzle openings. Procedia Technology, 25(Raerest), 974981. Recovered from https://doi.org/10.1016/j.protcy.2016.08.190

Chiyembekezo, K., Cuthbert, K., \& Torbjorn, N. (2014). A numerical investigation of flow profile and performance of a low cost crossflow 
2021, Instituto Mexicano de Tecnología del Agua

Tecnología y

Ciencias $₫$ Agua
Open Access bajola licencia CC BY-NC-SA 4.0

(https://creativecommons.org/licenses/by-nc-sa/4.0/)

turbine. International Journal of Energy and Environment, 5(3), 275-296.

Dragomirescu, A. (2016). Numerical investigation of the flow in a modified Bánki turbine with nozzle foreseen with guide vanes. Proceedings of the 2016 International Conference and Exposition on Electrical and Power Engineering, EPE 2016, Epe, 874-879. Recovered from https://doi.org/10.1109/ICEPE.2016.7781461

Olade, Organización Latinoamericana de Energía. (1987). Manual de diseño, estandarización y fabricación de equipos para pequeñas centrales hidroelectricas. Quito, Ecuador: Organización Latinoamericana de Energía. Recovered from http://biblioteca.olade.org/opac-tmpl/Documentos/old0194.pdf

Organization, UNID, United Nations Industrial Development Organization . (2016). World Small Hydropower Development Report 2016. Vienna, Austria: nited Nations Industrial Development Organization. Recovered

from

http://www.smallhydroworld.org/fileadmin/user_upload/pdf/2016/W SHPDR_2016_full_report.pdf

Paish, O. (2002). Small hydro power: Technology and current status. Renewable and Sustainable Energy Reviews, 6(6), 537-556. Recovered from https://doi.org/10.1016/S1364-0321(02)00006-0

Paredes-Gutiérrez, C. A., Palacio-Higuita, E. A., \& Goméz-Gómez, J. I. (2008). La turbina Michell-Banki y su presencia en Colombia. Avances de Recursos Hidraulicos, 17, 33-42. 
Paz, E. P., Carrocci, L. R., Filho, P. M., \& Luna, C. R. (2007). Metodología de diseño hidráulico y mécanico de una turbina MichellBanki. $8^{\circ}$ Congreso Iberoamericano de Ingeniería Mecánica, Cusco, Perú.

Popescu, D. (2017). Flow control in Banki turbines. Energy Procedia, 136 , 424-429.

Recovered

from

https://doi.org/10.1016/j.egypro.2017.10.272

Rantererung, C. L., Tandiseno, T., \& Malissa, M. (August, 2019).

Application of cross flow turbine with multi nozzle in remote areas. International Journal of Mechanical Engineering and Technology (IJMET), 10(08), 1-12. Recovered from http://iaeme.com/Home/issue/IJMET?Volume $=10 \&$ Issue $=8$

Sammartano, V., Morreale, G., Sinagra, M., \& Tucciarelli, T. (2016). Numerical and experimental investigation of a cross-flow water turbine. Journal of Hydraulic Research, 54, 321-331.

Sammartano, V., Morreale, G., Sinagra, M., Collura, A., \& Tucciarelli, T. (2014). Experimental study of cross-flow micro-turbines for aqueduct energy recovery. Procedia Engineering, 89, 540-547. Recovered from https://doi.org/10.1016/j.proeng.2014.11.476

Sammartano, V., Aricò, C., Carravetta, A., Fecarotta, O., \& Tucciarelli, T. (2013). Banki-Michell optimal design by computational fluid dynamics testing and hydrodynamic analysis. Energies, 6(5), 23622385. Recovered from https://doi.org/10.3390/en6052362

Shepherd, D. G. (1956). Principles of turbomachinery. New York, USA: 
Macmillan Company.

Tesfaye-Woldemariam, E., Lemu, H. G., \& Wang, G. G. (2018). CFDdriven valve shape optimization for performance improvement of a micro cross-flow turbine. Energies, 11(1), 248. Recovered from https://doi.org/10.3390/en11010248

Warjito, A. I., Siswantara, D., Adanta, A. P., \& Prakoso, R. D. (2017). Comparison between airfoil NACA-6712 profiled and ordinary blade in cross-flow turbine by numerical simulation. 15th International Conference on Quality in Research, Bali, Indonesia. 